\title{
Efektivitas Ekstrak Etanol Daun Sirsak (Annona muricata Linn) dalam Mencegah Displasia Dorsum Lingue Tikus Galur Sprague Dawley yang Diinduksi 7,12 Dimetilbenz(A)Antrasena
}

\author{
Tyas Prihatiningsih, ${ }^{1}$ Tetiana Haniastuti, ${ }^{2}$ Dewi Agustina $^{3}$
}

\author{
${ }^{1}$ Program Studi Kedokteran Gigi Fakultas Kedokteran, Universitas Diponegoro, Semarang, \\ Indonesia \\ ${ }^{2}$ Bagian Biologi Mulut, Fakultas Kedokteran Gigi, Universitas Gadjah Mada, Daerah Istimewa \\ Yogyakarta, Indonesia \\ ${ }^{3}$ Bagian Penyakit Mulut, Fakultas Kedokteran Gigi, Universitas Gadjah Mada, Daerah Istimewa \\ Yogyakarta, Indonesia \\ Email: tyasprihatiningsih@gmail.com
}

\begin{abstract}
Polycyclic aromatic hydrocarbons (PAH) is one of the largest group of carcinogen in the environment. An agent that has antigenotoxic and anticarcinogen potency is needed to prevent DNA damage and carcinogenesis. Soursop leaves have a chemopreventive action. This study was aimed to assess the effectiveness of ethanolic extract of soursop leaves in prevention of dysplasia of upper surface of tongue in rats. This was a true laboratory experimental study with the post test-only control group design, using 24 male Sprague Dawley rats divided into six groups. The upper surfaces of tongues of group I-III were induced by DMBA topically three times a week for 16 weeks; group II and III were induced by DMBA added soursop leaves ethanolic extract of 100 and $200 \mathrm{mg} / \mathrm{kg}$ body weight daily for 18 weeks; group IV was given soursop leaves ethanolic extract $200 \mathrm{mg} / \mathrm{kg}$ body weight; group V was given DMSO 1\%; and group VI was untreated. After 18th week, rats were terminated and tongue necropsies in longitudinal anteroposterior direction were conducted. The clinical changes of the upper surfaces of the tongues were observed and the histological changes were observed by using HE staining to confirm signs of dysplasia. The Kruskal Wallis test showed differences between groups, and the Mann-Withney test showed not significantly decrease of mild dysplasia of group II and group III compared to group I ( $p>0.05$ ). In conclusion, ethanolic extract of soursop leaves was not effective in prevention of dysplasia of the upper surface of rat's tongue.

Keywords: dysplasia; soursop leave extract; upper surface of tongue; DMBA
\end{abstract}

\begin{abstract}
Abstrak: Senyawa golongan PAH merupakan salah satu kelompok karsinogen terbesar di lingkungan. Sebagai upaya untuk mencegah kerusakan DNA serta karsinogenesis, diperlukan suatu agen yang berpotensi antigenotoksik sekaligus antikarsinogenik. Daun sirsak terbukti mempunyai aksi kemopreventif. Penelitian ini bertujuan untuk mengkaji efektivitas ekstrak etanol daun sirsak dalam mencegah displasia pada dorsum lingue tikus. Jenis penelitian ialah true experimental laboratory dengan the post test-only control group design yang menggunakan 24 ekor tikus galur Sprague Dawley jantan, dibagi dalam enam kelompok. Dorsum lingue tikus kelompok I - III diinduksi DMBA secara topikal tiga kali seminggu selama 16 minggu; kelompok II dan III selain diinduksi DMBA, juga diberi ekstrak etanol daun sirsak 100 dan $200 \mathrm{mg} / \mathrm{kg}$ berat badan setiap hari selama 18 minggu; kelompok IV diberi ekstrak etanol $200 \mathrm{mg} / \mathrm{kg} \mathrm{BB}$; kelompok V diberi DMSO 1\%; dan kelompok VI tidak diberi perlakuan. Terminasi dan nekropsi lidah tikus longitudinal anteroposterior dilaksanakan setelah minggu ke 18. Perubahan pada dorsum lingue diamati secara klinis dan perubahan histologik dilihat dengan pewarnaan HE untuk mengonfirmasi tanda displasia. Uji Kruskal Wallis menunjukkan perbedaan antar kelompok, sedangkan uji Mann Whitney menunjukkan penurunan tidak bermakna displasia ringan pada kelompok II dan III dibanding kelompok I. Simpulan penelitian ini ialah ekstrak etanol daun sirsak tidak efektif dalam mencegah displasia epitel dorsum lingue tikus.
\end{abstract}

Kata kunci: displasia; ekstrak daun sirsak; dorsum lingue; DMBA 


\section{PENDAHULUAN}

Senyawa golongan polycyclic aromatic hydrocarbon (PAH) merupakan polutan utama lingkungan dan tergolong salah satu kelompok karsinogen terbesar di lingkungan. ${ }^{1}$ Senyawa-senyawa PAH berpotensi untuk membentuk ikatan kimia serta dapat bergabung dengan senyawa lain sehingga senyawa ini tidak dapat teridentifikasi sebagai senyawa tunggal melainkan telah tergabung dengan senyawa lain atau karsinogen lain dalam lingkungan. ${ }^{2}$ Residu PAH yang berada di udara berupa suspensi partikulat dalam polutan udara sehingga paparan PAH dapat terjadi melalui inhalasi. Senyawa ini juga ditemukan dalam makanan dan dapat terbentuk selama proses memasak makanan. ${ }^{3}$ Dalam International Programme on Chemical Safety (1998) dinyatakan bahwa makanan merupakan sumber utama paparan PAH terhadap populasi umumnya. ${ }^{4}$

Senyawa 7,12-dimetillbenz( $\alpha$ )antrasena (DMBA) merupakan salah satu senyawa dari golongan PAH. Struktur kimia yang dimiliki DMBA memenuhi kriteria minimum potensi karsinogenik sehingga senyawa ini menjadi salah satu karsinogen yang paling poten. ${ }^{5}$ Senyawa ini banyak digunakan untuk menginduksi kanker rongga mulut pada hamster. ${ }^{6}$ Pada penelitiannya, Cavalcante et $\mathrm{al}^{7}$ menggunakan DMBA untuk menginduksi displasia pada lidah tikus. $^{7}$

Karsinogenesis rongga mulut merupakan suatu proses multifokal kompleks pada lapisan epitel skuamosa yang mengalami perubahan genetik. ${ }^{8}$ Perkembangan karsinogenesis dapat dideteksi dengan biomarker karsinogenesis. ${ }^{9}$ Berdasarkan rekomendasi Committee on Biological Marker of the National Research Council, biomarker karsinogenesis rongga mulut dibagi menjadi beberapa kategori, antara lain biomarker genomik, onkogen, stres oksidatif, proliferasi, apoptosis, diferensiasi, dan imunologi. ${ }^{8}$

Paparan polutan dan bahan-bahan kimia yang berpotensi karsinogen genotoksik dewasa ini tidak dapat dihindari. Untuk mencegah terjadinya kerusakan deoxyribonucleic acid (DNA) serta karsino- genesis sebagai bentuk dari kerusakan lebih lanjut, maka diperlukan suatu agen yang berpotensi antigenotoksik sekaligus antikarsinogenik. Potensi tersebut dimiliki oleh agen kemopreventif. Konsep kemopreventif diperkenalkan oleh Sporn pada tahun 1976, yaitu penggunaan agen tertentu untuk menekan maupun mengembalikan proses karsinogenesis sehingga dapat mencegah terjadinya suatu keganasan. ${ }^{10}$

Sirsak merupakan tanaman yang dapat tumbuh baik di Indonesia. ${ }^{11}$ Semua bagian tanaman sirsak dapat dimanfaatkan sebagai obat tradisional. ${ }^{12}$ Dari hasil penelitian diketahui bahwa daun sirsak mempunyai potensi kemopreventif. Pada beberapa penelitian secara terpisah, daun sirsak terbukti mempunyai mekanisme aksi kemopreventif di antaranya aktivitas antioksidan ${ }^{13}$ dan antiproliferasi. ${ }^{14}$ Secara fitokimiawi kandungan utama daun sirsak ialah senyawa golongan annonaceous acetogenin. Senyawa acetogenin telah dilaporkan pada beberapa penelitian mempunyai aktivitas antikanker. Beberapa penelitian in vivo menunjukkan aktivitas antikanker dan antitumor daun sirsak terhadap papilogenesis kulit mencit, ${ }^{11}$ displasia payudara tikus, ${ }^{15}$ dan tumor prostat tikus. ${ }^{16}$ Berdasarkan latar belakang yang telah dipaparkan maka penulis terdorong untuk mengkaji efektivitas ekstrak etanol daun sirsak terhadap pencegahan displasia epitel dorsum lingue tikus.

\section{METODE PENELITIAN}

Penelitian ini merupakan suatu penelitian true experimental laboratory dengan the posttest-only control group design, menggunakan tikus galur Sprague Dawley sebagai subjek penelitian. Kriteria subjek penelitian yang digunakan yaitu tikus jantan, berumur 5 minggu dengan berat 49$89 \mathrm{gr}$, dan sehat. Jumlah subjek penelitian yang digunakan sebanyak 24 ekor yang dibagi menjadi enam kelompok (I-VI). Kelompok I diinduksi DMBA; kelompok II dan III selain diinduksi DMBA juga mendapat suplementasi ekstrak etanol daun sirsak masing-masing $100 \mathrm{mg} / \mathrm{kg}$ BB dan 200 mg/kg BB; kelompok IV diberi ekstrak 
etanol daun sirsak $200 \mathrm{mg} / \mathrm{kg}$ BB tanpa DMBA; kelompok V diberi DMSO 1\% saja; dan kelompok VI tanpa perlakuan. Penelitian ini menggunakan DMSO $1 \%$ sebagai kontrol negatif; hal ini bertujuan sebagai pembanding bahwa pelarut yang digunakan sebagai pengencer tidak memengaruhi hasil dari senyawa yang diuji. ${ }^{17}$ Tikus Sprague Dawley yang diperoleh dari LPPT unit IV Universitas Gadjah Mada Yogyakarta diadaptasikan terhadap lingkungan kandang selama satu minggu. Tikus putih diberi makan pellet sebanyak 360 g per hari dan minuman air keran ad libitum diberikan melalui botol minum kaca.

Larutan 0,5\% DMBA dalam penelitian ini dibuat dengan melarutkan serbuk DMBA sebanyak $50 \mathrm{mg}$ ke dalam aseton $10 \mathrm{ml}$. Induksi larutan DMBA dilakukan pada dorsum lingue tikus menggunakan kuas lukis nomor empat dengan dua kali usapan dari arah posterior ke anterior. Perlakuan diberikan pada hewan coba tiga kali per minggu selama 16 minggu dan tidak menggunakan anastesi.

Pemberian ekstrak etanolik daun sirsak dosis $100 \mathrm{mg} / \mathrm{kg}$ dan $200 \mathrm{mg} / \mathrm{kg}$ berat badan dilakukan setiap hari dengan oral gavage. Ekstrak dilarutkan ke dalam DMSO 1\% menjadi $1 \mathrm{ml}$ ekstrak daun sirsak. Penelitian ini mengunakan DMSO sebagai pelarut karena DMSO merupakan pelarut aprotik yang mampu melarutkan berbagai macam molekul polar dan nonpolar yang sukar larut. ${ }^{18}$ Pada kelompok tikus yang diberikan DMSO $1 \%$ saja, pemberian larutan dilakukan dengan metode dan waktu yang sama seperti pemberian ekstrak etanolik daun sirsak.

Pada minggu ke-18 setelah perlakuan, dilakukan eutanasia hewan coba dengan injeksi ketamine $\mathrm{HCl}$ overdosis, selanjutnya tikus dikorbankan dengan cara dekapitasi. Lidah yang telah diberi perlakuan diambil, kemudian dipotong longitudinal posteroanterior. Hasil potongan lidah difiksasi dengan buffered formalin 10\%, selanjutnya dibuat blok parafin. Ketebalan potongan blok parafin untuk pengecatan hematoksilin eosin (HE) $5 \mu \mathrm{m}$. Sediaan diamati di bawah mikroskop dengan perbesaran 100 dan 400 kali untuk melihat perubahan arsitektur epitel dorsum lingue tikus.

Data yang diperoleh dari hasil pengamatan struktur dorsum lingue tikus secara klinis dan mikroskopik berupa data ordinal. Data penelitian dianalisis secara statistik dengan menggunakan uji Kruskal Wallis. Perbedaan struktur dorsum lingue tikus selanjutnya diuji dengan uji Mann Whitney.

\section{HASIL PENELITIAN}

Hasil penelitian pada dorsum lingue tikus setelah perlakuan menunjukkan bahwa terdapat progresivitas karsinogenesis. Diagnosis progresivitas karsinogenesis lidah tikus ditentukan berdasarkan penilaian kondisi histopatologik paling berat yang dijumpai pada masing-masing spesimen. Rangkuman diagnosis histopatologik lidah tikus ditampilkan pada Tabel 1.

Hasil penelitian ini menunjukkan bahwa pada kelompok yang diolesi DMBA, seluruh lidah tikus mengalami displasia ringan. Hal ini didukung oleh hasil pemeriksaan klinis pada lidah tikus yang mendapatkan adanya lesi leukoplakia (Gambar 1). Hasil pemeriksaan histopatologik mendapatkan adanya penebalan lapisan keratin atau hiperkeratosis dibanding lapisan keratin kelompok kontrol. Pada lapisan basal tampak hiperplasia sel basal, hiperkromatin, polimorfisme, serta posisi mitosis sel yang tidak normal di suprabasal (Gambar 2) Hasil pemeriksaan tersebut mengindikasikan bahwa terjadi displasia ringan pada lidah tikus yang diinduksi DMBA.

Pada tikus kelompok IV yang diberi ekstrak etanolik daun sirsak $200 \mathrm{mg} / \mathrm{kg} \mathrm{BB}$, kelompok V yang diberi DMSO $1 \%$ saja sebagai kontrol negatif, dan kelompok VI yang tanpa perlakuan tidak didapatkan displasia epitel dorsum lingue (Tabel 1).

Hasil analisis uji Kruskal Wallis mendapatkan nilai $p=0,001 \quad(p<0,05)$. Hal ini menunjukkan adanya perbedaan bermakna antar kelompok perlakuan. Analisis data selanjutnya menggunakan Mann Withney $U$ test yang menunjukkan adanya perbedaan struktur epitel dorsum lingue secara bermakna $(\mathrm{p}<0,05)$ antara kelompok I yang 
diinduksi DMBA dengan kelompok II dan III yang diinduksi DMBA dan diberi ekstrak etanol daun sirsak 100 dan $200 \mathrm{mg} / \mathrm{kg} \mathrm{BB}$; kelompok II yang diinduksi DMBA dan diberi ekstrak etanol daun sirsak $100 \mathrm{mg} / \mathrm{kg}$ BB dengan kelompok III yang diinduksi DMBA dan diberi ekstrak etanol daun sirsak 200mg/kg BB; sedangkan kelompok I yang diinduksi DMBA dengan kelompok IV yang diberi ekstrak etanol daun sirsak $200 \mathrm{mg} / \mathrm{kg}$ $\mathrm{BB}$, kelompok $\mathrm{V}$ yang diberi DMSO $1 \%$, dan kelompok perlakuan II dan III menunjukkan perbedaan struktur epitel dorsum lingue tikus secara bermakna.

\section{BAHASAN}

Pada penelitian ini dilakukan aplikasi topikal DMBA selama 16 minggu, dan hasil pengamatan secara klinis menunjukkan gambaran leukoplakia pada dorsum lingue tikus. Hal tersebut sesuai dengan hasil penelitian Kitakawa et $\mathrm{al}^{6}$ yang melaporkan gambaran lesi keputihan yang menyebar pada permukaan lateral lidah hamster setelah aplikasi topikal DMBA selama 4 minggu.

Hasil pemeriksaan lesi secara histopatologik setelah 16 minggu diinduksi DMBA menunjukkan gambaran hiperkeratin, hiperplasia sel basal, hiperkromatin, pleomorfisme sel, serta adanya mitosis di suprabasal yang terjadi pada sepertiga bawah. Gambaran histopatologik tersebut sesuai dengan penelitian Cavalcante et $\mathrm{al}^{7}$ yang mendapatkan gambaran hiperkeratinisasi, hiperplasia sel basal, hiperkromatin,

Tabel 1. Progresivitas karsinogenesis epitel dorsum lingue tikus

\begin{tabular}{lcccccc}
\hline \multicolumn{1}{c}{ Gambaran } & \multicolumn{5}{c}{ Kelompok Penelitian } \\
histopatologik lidah & I & II & III & IV & V & VI \\
\hline Normal & 0 & 0 & 0 & 4 & 4 & 4 \\
Hiperplasia & 0 & 1 & 2 & 0 & 0 & 0 \\
Displasia ringan & 4 & 3 & 2 & 0 & 0 & 0 \\
Total & 4 & 4 & 4 & 4 & 4 & 4 \\
\hline
\end{tabular}

Keterangan:

I Kelompok DMBA

II Kelompok DMBA + ekstrak etanolik daun sirsak $100 \mathrm{mg} / \mathrm{kg}$ BB

III Kelompok DMBA + ekstrak etanolik daun sirsak $200 \mathrm{mg} / \mathrm{kg}$ BB

IV Kelompok ekstrak etanolik daun sirsak $200 \mathrm{mg} / \mathrm{kg} \mathrm{BB}$

V Kelompok DMSO 1\%

VI Kelompok tanpa perlakuan

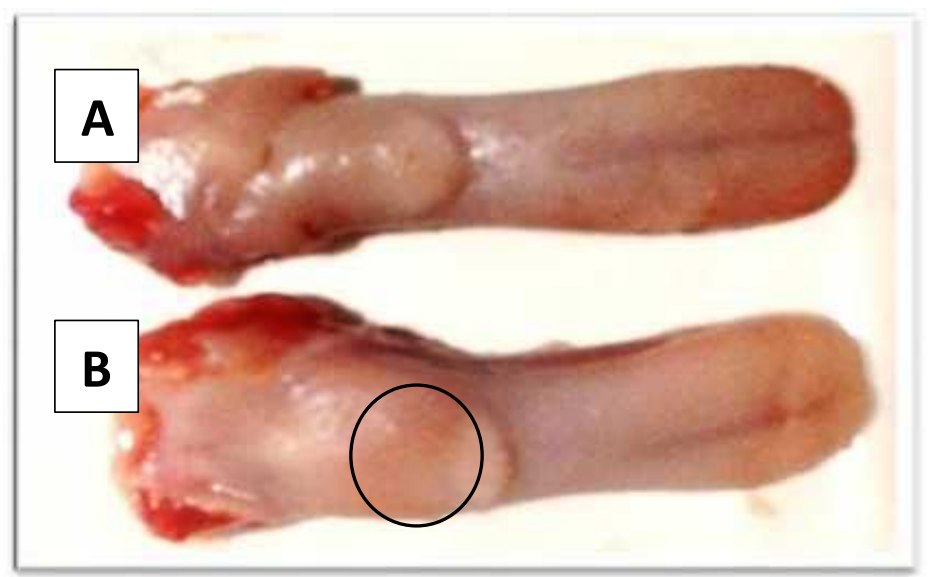

Gambar 1. A. Lidah tikus tanpa perlakuan tampak normal; B. Lidah tikus setelah diinduksi DMBA selama 16 minggu, tampak lesi leukoplakia (lingkaran hitam) 

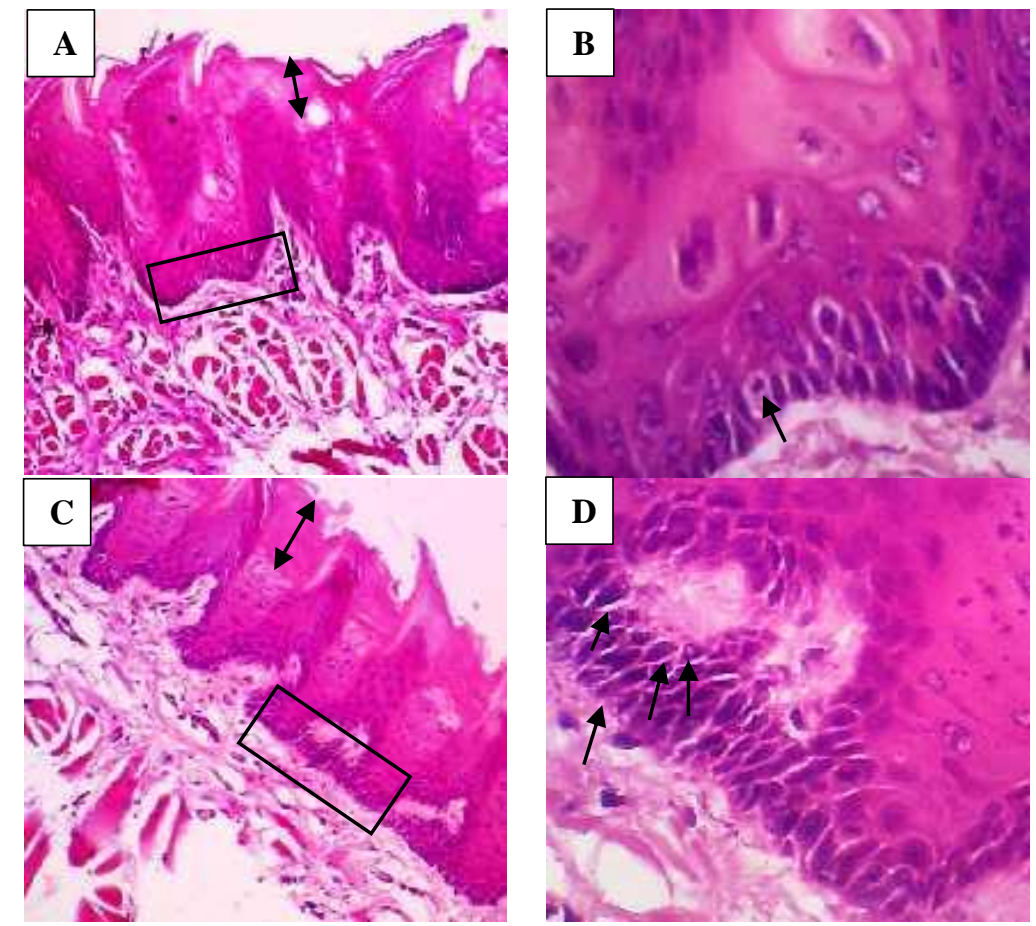

Gambar 2. Fotomikrograf epitel dorsum lingue tikus dengan pengecatan H\&E. (A) Kelompok kontrol menunjukkan epitel lidah normal, ketebalan lapisan keratin normal ( $\uparrow)$ (100x); (B) Perbesaran 400x ( $\square$ ) dari gambar A tampak adanya posisi mitosis normal di basal $(\downarrow)$. (C) Kelompok yang diinduksi DMBA menunjukkan peningkatan ketebalan lapisan keratin atau hiperkeratosis $(\uparrow)$ dibanding lapisan keratin normal (100x). (D) Perbesaran 400x ( $\square$ ) dari gambar $C$ tampak displasia epitel yang ditandai hiperplasia sel basal, mitosis basal $(\downarrow)$ dan suprabasal $(\downarrow)$, hiperkromatin dan plemorfisme sel basal $(\downarrow)$.

pleomorfisme sel, serta adanya mitosis di suprabasal yang terjadi lebih dari sepertiga bawah dari ketebalan epitel setelah induksi DMBA pada lidah tikus selama 20 minggu. Penelitian Kitakawa et al ${ }^{6}$ juga melaporkan adanya gambaran hiperkeratinisasi, pleomorfisme dan hiperkromatin pada lebih dari dua per tiga epitel setelah induksi DMBA pada lidah hamster selama 12 minggu. Lesi pada penelitian Cavalcante et $\mathrm{al}^{7}$ dikategorikan sebagai displasia sedang, sedangkan lesi pada penelitian ini berdasarkan klasifikasi WHO termasuk dalam kategori displasia ringan. ${ }^{19}$ Lesi pada penelitian ini dan pada penelitian Cavalcante et $\mathrm{al}^{7}$ menunjukkan kemiripan, hanya saja berbeda pada derajat progresivitasnya. Perbedaan tersebut dapat terjadi karena perbedaan durasi induksi karsinogenesis.

Berdasarkan durasi induksi DMBA terhadap karsinogenesis rongga mulut pada penelitian sebelumnya didapatkan bahwa induksi DMBA terhadap karsinogenesis rongga mulut hamster lebih efektif diban- ding induksi terhadap tikus pada penelitian ini dan penelitian Cavalcante et al. ${ }^{7}$ Menurut Kitakawa et al, ${ }^{6}$ hal tersebut kemungkinan disebabkan oleh perbedaan kerentanan spesies model hewan coba dalam proses tumorigenesis. Model induksi DMBA pada karsinogenesis rongga mulut tikus memberikan alternatif dalam pemilihan model hewan induksi meskipun induksi karsinogenesis DMBA pada rongga mulut tikus kurang efektif dibandingkan hamster.

Displasia merupakan salah satu tahap perubahan histopatologik dalam proses karsinogenesis, ${ }^{20}$ sehingga mekanismenya mungkin merupakan bagian dari mekanisme karsinogenesis. Mekanisme displasia diperkirakan melibatkan gen-gen yang berperan dalam proliferasi dan diferensiasi sel. Beberapa gen dan protein yang terlibat dalam proliferasi pada displasia rongga mulut yang mengalami perubahan di antaranya ialah gen p53, p21, p16, ${ }^{8} \mathrm{pRb}$, CDKN2A, ${ }^{21}$ sedangkan protein cyclin Dl mengalami peningkatan ekspresi dan p27 
mengalami penurunan regulasi. ${ }^{22}$ Perubahan tersebut menyebabkan gangguan siklus sel dan peningkatan proliferasi. ${ }^{21,22}$ Hal ini ditunjukkan dengan adanya peningkatan proliferasi sel epitel pada displasia ringan lidah tikus dalam penelitian ini. Gangguan diferensiasi pada displasia diperankan terutama oleh gen NOTCH dan regulatornya yaitu p63. Pada kasus displasia, ekspresi p63 ditemukan mengalami peningkatan di lapisan suprabasal sehingga ekspresi protein Notch menurun; hal ini mengakibatkan gangguan diferensiasi tahap lanjut pada epitel bertingkat. ${ }^{21}$

Efek ekstrak etanolik daun sirsak pada penelitian ini tampak pada kelompok II yang diinduksi DMBA dan diberi ekstrak etanolik daun sirsak $100 \mathrm{mg} / \mathrm{kg}$ BB yang menunjukkan displasia ringan pada tiga tikus dan hiperplasia pada satu tikus. Kelompok III yang diinduksi DMBA dan diberi ekstrak etanolik daun sirsak $200 \mathrm{mg} / \mathrm{kg}$ BB juga menunjukkan displasia ringan pada dua tikus dan hiperplasia pada dua tikus. Hal tersebut menunjukkan bahwa ekstrak etanolik daun sirsak mempunyai efek menurunkan progresivitas karsinogenesis pada tikus yang diinduksi DMBA. Hal ini sesuai dengan penelitian Hamizah et al $^{11}$ yang melaporkan efek ektrak etanolik daun sirsak terhadap penurunan terjadinya tumor kulit tikus melalui penghambatan pada tahap inisiasi dan promosi papilomagenesis yang diinduksi DMBA.

Penurunan progresivitas karsinogenesis pada penelitian ini diduga berkaitan dengan efek antikanker yang dimiliki ekstrak etanolik daun sirsak. Efek antikanker ekstrak etanolik daun sirsak diduga berkaitan dengan kandungan senyawa acetogenin dan flavonoid daun sirsak. Efek antikanker daun sirsak dapat terjadi melalui beberapa mekanisme di antaranya menghambat proliferasi, ${ }^{15,23}$ menginduksi apoptosis, ${ }^{23}$ meningkatkan ekspresi $\mathrm{p} 53,{ }^{24}$ dan melalui aktivitas antioksidan. ${ }^{13}$

Analisis statistik data hasil penelitian menunjukkan tidak terdapat perbedaan terjadinya displasia ringan yang bermakna antara kelompok tikus yang diinduksi DMBA dengan kelompok tikus yang diinduksi DMBA dan diberi ekstrak etanol daun sirsak $100 \mathrm{mg} / \mathrm{kg} \mathrm{BB}$ dan $200 \mathrm{mg} / \mathrm{kg}$ BB. Hal ini mungkin disebabkan karena jumlah sampel masih kurang banyak sehingga tidak menunjukkan efektivitas ekstrak etanol daun sirsak dalam mencegah displasia ringan dorsum lingue tikus.

\section{SIMPULAN}

Ekstrak etanol daun sirsak dalam penelitian ini tidak efektif dalam mencegah displasia epitel dorsum lingue tikus yang diinduksi DMBA.

\section{Konflik Kepentingan}

Penulis menyatakan tidak terdapat konflik kepentingan dalam studi ini.

\section{DAFTAR PUSTAKA}

1. Tudoran MA, Putz MV. Polycyclic aromatic hydrocarbons: from in cerebro to in silico eco-toxicity fate. Chem Bull "Politehnica" Univ (Timisoara). 2012; 57(71):50-3.

2. U.S. Department of Health and Human Services. Report on Carcinogens (12th ed). Public Health Service, National Toxicology Program. 2011.

3. Bonner M, Han D, Nie J, Rogerson P, Vena J, Muti, $\mathrm{P}$, et al. breast cancer risk and exposure in early life to polycyclic aromatic hydrocarbons using total suspended particulates as a proxy measure, Cancer Epidemiology Biomarkers Prevention. 2005;14:53-60.

4. IPCS. Environmental Health Criteria No. 202. Selected non-heterocyclic polycyclic aromatic hydrocarbons. International Programme on Chemical Safety. 1998 [cited 2014 Sep 9]. Available from: http://www.inchem.org/documents/ehc/ ehc/ehc202.htm.

5. King RJB. Cancer Biology (2nd ed). London: Pearson Education, 2000.

6. Kitakawa D, Cabral LAG, Marques MEA, Salvadori DMF, Ribeiro DA. Mediumterm tongue carcinogenesis assays: A comparative study between 4-nitroquinoline 1-oxide (4NQO)-induced rat and dimethylbenzanthracene (DMBA)induced hamster carcinogenesis. JEANS. 2006;43:219-27.

7. Cavalcante DRR, Oliveira PS, Gois SM, Soares 
AF, Cardoso JC, Padilha FF, et al. Effect of green propolis on oral epithelial dysplasia in rats. Braz $\mathrm{J}$ Otorhinolaryngol (Impr.). 2011;77(3):278-84.

8. Tanaka T, Ishigamori R. Understanding carcinogenesis for fighting oral cancer: Review Article. Journal of Oncology. 2011; 2011:1-10. Article ID 603740. Available from: https://doi.org/10.1155/2011/ 603740.

9. Ali S, Bansal P, Bhargava D, Kunal V. Biomarker: validation, characteristics, pitfalls and importance in oral squamous cell carcinoma. JEMDS. 2015; 4:88-94.

10. Kakizoe T. Chemoprevention of cancer focusing on clinical trials, Jpn J Clin Onco. 2003;133(9):421-42.

11. Hamizah S, Roslida AH, Fezah O, Tan KL, Tor YS, Tan CI. Chemopreventive potential of Annona muricata L. leaves on chemically-induced skin papilloma genesis in mice. APJP. 2012;13:2533-9.

12. Taylor L. Technical data report for Graviola (Annona Muricata), Austin: SagePress, Inc, 2005 [cited 2014 Sep 11]. Available from: http://rain-tree.com/reports/ graviola-techreport.pdf.

13. Baskar R, Rajeswari V, Kumar TS. In vitro antioxidant studies in leaves of Annona species. Indian J Exp Biol. 2007;45(5): 480-5.

14. Moghadamtousi ZS, Fadaeinasab M, Nikzad S, Mohan G, Ali HM, Kadir HA. Annona muricata (Annonaceae): A review of its traditional uses, isolated acetogenins and biological activities. Int. J Mol Sci. 2015;16:15625-58.

15. Minari JB, Okeke U. Chemopreventive effect of Annona muricata on DMBA induced cell proliferation in the breast tissues of female albino mice. Egypt J Med Hum Genet. 2014;15(4):327-34.

16. Asare GA, Afriye D, Ngala RA, Abutiate H, Doku D, Mahmood SA, et al. Antiproliferative activity of aqueous leaf extract of Annona muricata $L$. on the prostate, $\mathrm{BPH}-1$ cells, and some target genes. Integr Cancer Ther. 2015;14(1): 65-74.

17. Suryadi BU, Mita F, Warih PL dan Sri M. Uji aktivitas antibakteri C-4-metoksifenilkaliks[4]resorsinarena termodifikasi hexadecyltrimethylammonium-bromide terhadap bakteri Staphylococcus aureus dan Eserchia coli. JKPK. 2018;3(3): 201-9.

18. Joana G, Benjamin D, Mark T, Eduardo N, Michael RD, Francesca MC. Unexpected low-dose toxicity of the universal solvent DMSO. FASEB J. 2014;28 (3):1317-30.

19. Carmo MAV, Caldeira PC. Binary system of grading epithelial dysplasia in oral leukoplakias in carcinogenesis. 2013 (cited 2016 Jan 21]. Available from: www.intechopen.com/book.

20. Mendez RA. Oncogenic pathways in the development of oral cancer. Carcinogenesis \& Mutagenesis. 2012;3(2). Doi:10.4172/2157-2518.1000133

21. Rothenberg SM, Ellisen LW. The molecular pathogenesis of head and neck squamous cell carcinoma, J Clin Invest. 2012;122:1951-6.

22. Ramasubramanian AS, Ramani P, Sherlin HJ, Premkumar P, Natesan A. Thiruvengadam, C. Immunohistochemical evaluation of oral epithelial dysplasia using cyclin-D1, p27 and p63 expression as predictors of malignant transformation. J Nat Sci Biol Med. 2013; 4(2):349-58.

23. Rachmawati E, Karyono S, Suyuti H. Efek ekstrak etanolik daun sirsak pada proliferasi dan apoptosis sel HeLa yang dimediasi oleh p53. J Kedokt. Brawijaya. 2012;27(1):28-33.

24. Astirin OP, Prayitno A, Artanti AN, Fitria MS, Witianingsih DA, Pranatami DA, et al. The expression of p53 and hsp70 proteins after treatment with Annona muricata Linn leaf for activating apoptotic and lead to homeostasis program of Raji cells. Int J Cancer Ther Onco. 2014;2(2):1-6. 